\title{
A FUTURE PERSPECTIVE ON TOURISM AND CULTURAL DYNAMICS
}

\author{
Rami K. Isaac \\ Senior Lecturer \\ Centre for Sustainability, Tourism and Transport \\ Breda University of Applied Sciences \\ Address: Mgr. Hopmanstraat 2, 4817 JT, Breda, The Netherlands \\ Email: Isaac.r@buas.nl \\ Vincent Platenkamp \\ Professor Cross-Cultural Understanding \\ Academy for Tourism \\ Breda University of Applied Sciences
}

Deleuze's concept of a rhizome makes us better understand the necessary, new and creative entrances in our social scientific enterprise. There is a great need for this creativity, especially in the more specialized areas of tourism studies. Tourism academics have the self-sufficient and dull tendency to stick to their own, and safe paradigms. They stick to their little islands (Platenkamp, 2015) and look away from the adventurous potentialities of the undiscovered open sea, where the smart Odysseus tried to reach Ithaca. Ithaca stands for the place where an academic ideal has been constituted of a quest of the truth, although everyone realizes that truth will never be reached. This quest, then, does not take place on Ithaca but in more realistic places in this post-colonial, glocalising, post-modern, modern, traditional, transnational, national, regional, local and many more to be qualified characteristics in this open sea, which is our 
contemporary world. From their safe, paradigmatic islands tourism academics will never be able to see the other islands and what the quest in the open sea might deliver them. When you realize the complexity and inter-connectivity of this network-society you start to understand the usefulness of a challenging concept like a rhizome with its many theoretical and practical entrances that allowing creativity where the acception of dissensus is as realistic as the search for consensus. Looking for cultural dynamics in tourism studies, implies the importance of pluralism within the concept of a rhizome with its many entrances to what might be called academic truth.

In this special issue an attempt has been made to create room for these various entrances. We were not bothered by the limited claims of any paradigm as an overall scheme to adapt to, we were looking for creative approaches and for quality, for many paradigmatic or not developments in the field of cultural dynamics. There probably exists a rhizomatic interconnectivity between the paradigmatic islands with various entrances. This refers to the need of a more critical stream of thought in tourism studies that needs to be articulated and this special issue is an attempt to penetrate deeper into the field of cultural dynamics within this rhizomatic critical stream.

Various articles presented in this special issue gave attention to the field of cultural dynamics. Ooi in his example of Singapore, gave the perspective of literary studies, which is most welcomed in this rhizomatic critical studies. Min Zhang in her studies on China and Vietnam, who tries to understand the transformation processes in a highly heterogeneous community in the border area between China and Vietnam. Fagence in his article, in addition, emphasises the importance of pluralist interpretations in his original involvement where he is 'teasing out' what cultural heritage landscapes and historic sites have 'to say'. Kuntz for example reflects on the dynamics that started to appear in Battir, Palestine, as in spite of tourism 
development's challenges in a conflict zone, the inhabitants started to react to the UNESCO World Heritage status of village lands and traditional agriculture and offer services to visitors. The article of Díaz-Carrión and Vizcaino-Suárez focusses on tourism and gender in Latin America, the authors point, again in this special issue, to the need for richer and more diverse (gender) frameworks in a globalizing world where cultural dynamics comes from everywhere and different directions and approaches. The final two articles mentioned in this special issues, the one written by $\mathrm{Su}$ and Cai, entitled "From Cultural Governance to Cultural Tourism: Towards an Interpretation Approach" challenge to address cultural dynamics between symbolism and signification and to demonstrate their relationship within tourism through the studies of cultural governance and cultural tourism. Atai, for example, draws from the work of unwanted heritage or heritage that hurts, and politics in the case of Afghanistan with the bombardment of the Buddhas. Atai made an attempt to reveal the main impulses that might have led to the destruction of Buddha statues by Taliban in the Bamiyan Valley of Afghanistan. All these articles give significant attempt to penetrate into the field of cultural dynamics within the rhizomatic critical studies, which is needed.

This special issue has been limited to tourism academics, but the rhizome challenges us to do more. Are there other study areas, related in some way or another to tourism, that are rhizomatically interconnected to tourism studies as conceived of in this special issue? The article entitled Imagined relational capital: An analytical tool in considering small tourism firms'sociality (Saxena, 2015), illustrates such a new opportunity focusing in a microscopical manner on "relational encounters and exchanges that take place at the molecular plane of the virtual to offer discreet insights into small tourism firms, understandings of their world and their places within it" (Saxena, 2015, p. 116). Should we as tourism academics not confront us and the others in diverse cross-sectional ways more with our and their findings? Other research agendas that could be developed are the 
following: (1) On sustainability: What would be happen to the tourism industry if the reduction of airplanes would maximally reduce its contribution to pollution? Different scenarios could be elaborated from various disciplines with diverse perspectives; (2) micro-analyses from various perspectives on host-guest relations with cultural heritage sites. These relations could be conceived as revisions of the host-guest relations, the tourism studies and academia are perpetually enclosed by the eye of empire that sought to gaze upon exotic others. Moving beyond this straight-jacket modality is the challenge of tourism studies. A question could be how does the liquid society (Baumann, 2000) influence these relations? Which voices are underrepresented and how to include them?; (3) every utopia turns into a dystopia (Isaac, 2015) as point of departure for rhizomatic research with various perspectives and disciplines into ideologies of tourism development that turn into dystopias. Palestine is an example of such development and the question, again is how to deal with this. In addition, artists are to be invited more. How can they interplay with tourism studies?. Which entrances could be discovered within the context of cultural dynamics that can be and are relevant to tourism studies? In this rhizomatic quest, we would be loyal, on the one hand, to our theoretical and empirical backgrounds as tourism academics. But at the same time we would choose the open sea and open up to what artists have to say about the culturaldynamics within tourism. A new special issue about different voices in Battir, about a parachutist view of history within a pluralist approach in cultural landscapes, about constructing collective, cultural identities in border territories like the one on the border of Vietnam and China or about the possible collapse of interpretations when power speaks as in the article of the destruction of Buddha in Afghanistan, might be a good venue for this confronting idea. Artists will have their own focus on these special issues, they are not bothered at all by our necessary theoretical and empirical backgrounds, but they will be interested, particularly in the qualitative results of organic research in the area, in storytelling as a way to 
do research on a deeper level, in pluralist interpretations and the way tourism academics are using them. This special issue could be the start of a promising research agenda with academics and artistic participants under the aegis of rhizomatic interconnectivity.

\section{References}

Bauman, Z. (2000) Liquid Modernity. Cambridge: Polity Press.

Platenkamp, V. (2015). The academic insula: The search for paradigm and for tourism studies. Tourism Analysis, 20, 561-571.

Isaac, R. K. (2015). Every utopia turns into dystopia. Tourism Management, 51, 392-330.

Saxena, G. (2015). Imagined relational capital: Am analytical tool in considering small tourism firms' sociality. Tourism Management, 49, 109-118. 